\title{
Beyond Loyalty: Alternatives to Employment
}

\section{Ken Phillips}

$\mathrm{E}$

MPLOYMENT is so much part of everyday life that few people know or care about its legal meaning. Yet most people would be surprised to discover the legal definitions of employment and how these affect their lives.

When people become employed, they enter a legal relationship in which the employer has the 'right to control' them. This legal power is evident in the provisions of some awards. For example, the Furnishing Trades Award states that 'no weekly employee shall work for more than one employer during any one week nor shall an employec make or assist in the production of goods for sale on his own account,. If such provisions were included in a contract between two companies, they would surely be considered an illegal restraint of trade. The provisions are no doubt underenforced, though not necessarily for the want of trying.

The right to control may, conversely, require employees to work beyond normal hours. In one case, an employee of a welding company, after working a 50hour week, didn't want to work overtime. But the court ruled that the employer had the right to control the employee and demand overtime. The employment test being applied was the employee's 'obligation to work' for the employer.

\section{The Right to Control}

How can such things happen? The law governing Australia's employment practices can be traced back to the master-servant relationship in English feudal law and practice. By the time of the industrial revolution, individuals were legally free, but during working hours the master-servant relationship applied, which made workers 'chattels' of the 'master'. The master-servant relationship has since evolved into the employer-employee relationship, in which the power to 'control' has been reduced to the 'right to control'. Clearly, some fine legal distinctions are involved here.

In determining whether employment legally exists, Australian industrial relations courts apply several tests, the most important of which is the 'control' test. If an employer has no demonstrable 'right to control an employee', employment does not legally exist. For example, an industrial relations court recently determined that

\footnotetext{
Furnishing Trades Award 1981 (ODN C No. 01333 of 1977) (Print E9473 F0029), Clause 8, 'Limitations of Employment' (a).

2

Odco Pty Ltd v Building Workers' Industrial Union of Australia and Others (1989), Federal Court of Australia, No. VG 151 of 1988, Woodward, J. 24 August, Melbourne (unreported), section 7.

3 '. . . the importance of control lies not so much in its actual exercise, although clearly that is relevant, as in the right of the employer to exercise it' Odco Pty Ltd $v$ Building Workers' Industrial Union of Australia and Others (1989): section 7.
} 
a taxi driver was not an employee of the taxi owner because the relationship was not one of master and servant but the medieval one of 'bailer to bailee'.

In many instances, the employer-employee relationship is really an employeeemployee relationship. Most employers are companies owned by distant shareholders, or government departments nominally owned by the general public; the employer function is a undertaken by managers who exercise controlling rights over other employees but who are themselves subject to control by other employees further up the scale. This compounds the legal complexity of employment and dilutes accountability.

\section{Limiting the Right to Control}

Concern over the abuse of the right to control has led to legal limitations on the power of employers. In Australia, the right to control is highly constrained by legislation, regulation and institutionalised attitudes and practices. For example, employers have lost the ultimate control mechanism - the right to dismiss an employee - because the courts have the power to overturn 'unfair' dismissals.

Many employers argue that the constraint on their control power is so extensive that employees and their representative institutions effectively control employers. But virtually none of the parties to the debate in Australia on employment and industrial relations questions the appropriateness of employment itself as the dominant form of work organisation. These constraints reflect the political and cultural power of the institutions that regulate employment. Such regulation limits commercial competition and delivers near-monopoly privileges to organisations adept at dealing within the official and unofficial regulatory environment. The key institutions in Australia's industrial-relations system have vested interests in maintaining the employment status quo: employers demand the right to control, while the unions and the regulatory bodies demand the right to limit that control. None of the present proposals for reforming Australia's industrial-relations system really moves beyond those boundaries.

But perhaps the main reason for the retention of employment is attitudinal. Managers have difficulty in understanding how they can improve performance if they can't exercise a right, however constrained, to control their workers. As one employer told me, 'All I want from my employees is for them to be there when I want them, for them to do what I want, and for me to be able to get rid of them when I don't want them.'

But managers are also concerned about security, safety and confidentiality. Businesses and organisations are commonly afraid of losing trained and talented people, of corporate skills going to rivals, of industrial and commercial espionage and of being held accountable in the event of accidents. Managers believe they can deal with these problems only if they exercise some kind of additional hold over their employees. Many of them therefore go to great lengths to motivate their

\footnotetext{
${ }^{4}$ Federal Industrial Relations Court, Cumberland Cabs (NI 95/3601. No. 703/95), 15 December 1995.
} 
workers to support the goals of the organisation beyond their strict legal obligations: in short, to win their loyalty.

In reality, fostering loyalty is an ownership-enhancing exercise that bolsters managers' right to control in an environment where that right is closely constrained by employment regulation. The trouble is that circumstances change and things go wrong. A business downturn or a corporate takeover may mean that the promises implied as part of the loyalty-building exercise cannot be kept. Attempts to hold employees through loyalty cannot ultimately be commercially sustained. The speed with which organisations, small and large, rise and fall in a competitive world attests to the weakness of loyalty and ownership. A recent study on workplace trends in the United States observed that corporate loyalty is really a form of dependency that grows from an inability of individuals to be self-sufficient (Bridges, 1996).

\section{Modes of Non-Employment}

Employees generally have no understanding of the legal reality within which they work. Businesses find that their use of workers is substantially controlled by outsiders who neither know nor care about the commercial environment within which they operate. The result is the suppression of competitive, successful businesses and the restriction of income opportunities for citizens.

But fundamental change has already begun, spurred by the global changes taking place in the work structures of developed economies. Bridges (1996) claims that this change is as significant as that of the industrial revolution itself. Employment as a dominant organisational and social structure is collapsing. The shift is most evident in the United States but is starting to happen also in Australia.

Two of the best-known and fastest-growing alternatives to employment in Australia are franchising and outsourcing, which involve the removal of the legal employment relationship between the head company or service user and the worker. As well, direct business-to-worker contracting is prevalent in the computer and courier industries and involves a wide variety of contract models. However, direct contracting lacks a clear legal definition, which is causing commercial confusion. Many people utilising direct contracting believe that statutory obligations, including workcover, payroll tax and superanuuation, do not apply. But the Australian Tax Office and other government revenue-collecting bodies are using the courts and legislation to narrow the legal definition of contracting so as to maximise their revenue collecting capacities. This is normally effected by having contractors declared 'employees' or 'deemed employees' for the purposes of statutory obligations. Take the Crisis Couriers case of 1995. Crisis Couriers believed that the contractor couriers, not the company, were legally liable for superanmuation payments. The court decision resulted in the contractors being declared employees, and Crisis Couriers was held liable for unpaid superamnuation (Australian Financial Review, 6 April 1995).

The commercial confusion caused by the lack of legal definition is substantial. In Australia, for workers to be legally declared contractors, each particular contracting method has to be tested in the High Court before it can reliably be said not to risk being deemed to be employment. Only one known direct contracting system 
has been sanctioned by the judiciary: agency contracting received a final positive High Court ruling in 1991 (Phillips, 1995). Under agency contracting, individual contractors are supplied as contractors to businesses through an administrative agency. No employment relationship exists at law.

Some managers, faced with the loss of their legal right to control the workers, suffer from a conceptual paralysis so serious that they cannot cope with contracting. They prefer to retain the employer-employee relationship and either put up with the regulatory regime or lobby to shift the employment relationship in their own favour. For them, the unavoidable changes occurring in the workplace pose a serious attitudinal challenge. But the workforce generally has the same problem.

\section{Concluding Comments}

The development and growth of franchising and outsourcing in Australia, the struggles with different forms of contracting and the growth of the legally secure agency contracting system demonstrate that the jobshift evident in the United States is developing momentum in Australia. The challenge is to think of each individual as a business, with assets, skills, and, above all, the freedom to negotiate an infinite variety of contracts with other businesses. Such one-person businesses need be loyal only to their own professionalism and reputation.

The allegedly widespread job insecurity that has followed the globalisation of some developed economies, such as the United States, Australia and New Zealand, stems largely from an inability to conceive of working in any way other than by being 'employed' by an 'employer' who does all the necessary thinking. But technological, legal and organisational changes are at last bringing down the high transaction costs that have in the past propped up socialistic command-and-control mechanisms at the workplace in place of market ones. Of course, wage employment will always have its place, to the extent that businesses and workers prefer it to the alternatives. But non-employment has the potential to remove the unequal power relationship and the class stratification, with its accompanying mixture of control, conflict and unrequited loyalty, imposed by employment law. It brings about the end of wage slavery envisaged by Karl Marx and Friedrich Engels, but in a way they certainly did not envisage: by the full development of capitalism, not its overthrow.

\section{References}

Bridges, W. (1996), How to Prosper in a Jobshift Workplace Without Jobs, Allen \& Unwin, Sydney.

Phillips, K. (1995), 'Do-It-Yourself Labour Market Reform: The Promise of Agency Contracting', Agenda 2(2): 259-62.

Ken Phillips is a Melbourne-based workplace reform practitioner.

$\overline{5}$ Odco Pty Ltd v Building Workers' Industrial Union of Australia and Others (1985): 5. 